\title{
Effect of Birth Ball Exercising for the Management of Childbirth Pain in Turkish Women
}

\section{Türk Kadınlarında Doğum Ağrısı Yönetiminde Doğum Topu Egzersizinin Etkisi}

(D) Demet AKTAŞ1, iD Sevil KOLSUZ², iD Mukadder ERTUĞRUL33, iD Elif Gizem BEŞiRLİ', iD Fatma Reyyan GÜNDOĞAN5

${ }^{1}$ Çankırı Karatekin University Faculty of Health Science, Department of Midwifery, Çankırı, Turkey

2Bülent Ecevit University Health Practice and Research Hospital, Zonguldak, Turkey

${ }^{3}$ Gazi University Hospital, Ankara, Turkey

${ }^{4}$ Bayındır Hospital, Ankara, Turkey

${ }^{5}$ Ankara Keçiören Training and Research Hospital, Ankara, Turkey

\section{ABSTRACT}

Objective: To investigate the effect of the birth ball exercise on management of childbirth pain during the first stage of labor in primipara pregnant women.

Methods: This was a semi-experimental randomized controlled study conducted on pregnant women between February and May 2016. The women were randomly categorized into 2 groups, with 30 women in each group (intervention vs. control groups). The pain visual analog scale (VAS) was used to determine the pain level of the women. Women in the intervention group were provided with a birth ball exercise program during labor. The control group performed no birth ball exercises. The VAS pain scores of the both the groups were registered when the cervical dilatation was $2-8 \mathrm{~cm}$. The data were analyzed using means, t-test, and ANOVA.

Results: Our results indicate that the pain scores of the women in the intervention group who implemented birth ball exercises were significantly lower than those of women in the control group when the cervical dilatation was $4-8 \mathrm{~cm}$.

Conclusion: The pain severity was "moderate" in the intervention group, but "severe" in the control group. Birth ball exercises were therefore found to be effective in decreasing childbirth pain in this study.

Keywords: Birth ball exercises, childbirth, childbirth pain, management of pain, methods of non-pharmacologic

\section{ÖZ}

Amaç: Bu çalışmanın amacı, doğum eyleminin birinci evresindeki primipar gebelerde doğum ağrısının yönetiminde doğum topu egzersizinin etkisini belirlemektir.

Yöntemler: Bu çalışma Şubat-Mayıs 2016 tarihleri arasında gebe kadınlarla yürütülen yarı deneysel randomize kontrollü bir çalışmadır. Çalışmada kadınlar rastgele iki gruba ayrıldı ve her gruptan 30 kadınla tamamlandı (müdahale-kontrolü). Kadınların ağrı düzeyini belirlemek için ağrıda görsel analog skala (VAS) kullanıldı. Müdahale grubundaki kadınlara doğum sırasında doğum topu egzersizi uygulandı. Kontrol grubuna ise doğum top egzersizi uygulanmadı. Her iki grubun VAS ağrı skorları servikal dilatasyon 2 cm'den 8 cm'ye kadar kaydedildi. Veriler ortalama, t-testi, ANOVA kullanılarak analiz edildi.

Bulgular: Çalışma bulgularımız, müdahale grubundaki doğum topu egzersizi uygulanan kadınların servikal dilatasyonu $4 \mathrm{~cm}$ 'den 8 cm'ye kadar olduğunda ağrı skorlarının kontrol grubundaki kadınlardan anlamlı derecede düşük olduğunu göstermektedir.

Sonuç: Müdahale grubunda ağrı şiddeti “orta” iken kontrol grubunda "şiddetlidir". Dolayısıyla bu çalışmada doğum topu egzersizinin doğum ağrılarını azaltmada etkili olduğu bulunmuştur.

Anahtar Sözcükler: Doğum topu egzersizi, doğum, doğum ağrısı, ağrının yönetimi, farmakolojik olmayan yöntemler

Address for Correspondence: Demet AKTAŞ, Çankırı Karatekin University Faculty of Health Science, Department of Midwifery, Çankırı, Turkey

E-mail: daktas7706@gmail.com ORCID ID: orcid.org/0000-0003-1206-4004 


\section{Introduction}

Birth is a natural process that can be managed without any medical intervention (1) and is a happy life event for most women (2). However, some physiological factors (such as uterine contractions), psychosocial factors (such as fear and anxiety) experienced by woman during labor, as well as the cultural practices and acquired knowledge on this subject possibly aggravates the discomfort associated with childbirth pain (35). Managing childbirth pain effectively and keeping it under control are therefore important. Childbirth pain is not a natural and inevitable experience for every woman.

Childbirth pain can be managed effectively by various approaches, such as through pharmacological or non-pharmacological methods. Narcotics, sedatives, epidural, and general anesthesia can be used as the pharmacological intervention agents (6). In addition, these methods provide effective analgesia and can sometimes cause medical side-effects such as fetal distress and the loss of the sense of pushing $(6,7)$. Therefore, several women prefer non-pharmacologic interventions (such as birth ball, massage, Lamaze, yoga, massage, aromatherapy, and the use of hot and cold packs) for the management of childbirth pain $(2,8,9)$. Because these non-pharmacologic methods can provide an adequate decrease in the pain experienced during childbirth and offer several benefits, they have no side-effect on the mothers or fetuses. Moreover, they do not prevent the progress of labor and there is no possibility of developing any allergic reaction. However, these interventions can decrease the excitement and anxiety of the mother. They increase the blood flow to the uterus and decrease the muscle tension as well as increase the birthrelated motivation of the pregnant woman with effective care offered during the prenatal period $(9,10)$. Considering these points, the goal of all non-pharmacologic intervention was to build a mother's confidence in her ability to give birth through the presentation of classes that help pregnant women understand how to cope with pain in ways that both facilitates labor and promotes comfort. At this point, it is therefore important for nurses to teach a few effective non-pharmacological approaches to pregnant women during the prenatal period. The best time for teaching them is the second trimester of pregnancy to a few weeks prior to the term $(6,11)$.

Recently, one of the effective non-pharmacological methods useful in the control of childbirth pain is reported to be birth ball exercising. This exercise improves the blood flow to the uterus in pregnant women by ensuring relaxation in the pelvic region muscles, which reduces the pain. In addition, the birth ball exercising improves the associated comfort and decreases pain by relaxing the back muscles in these pregnant women. Focusing on the movements and positions during exercise decreases a pregnant woman's attention and perception of pain $(3,12)$. The birth ball exercise has been found to decrease the pain in the pelvic region and back $(8,13,14)$ during labor, facilitates fetal progression through the birth channel, shortens the latent phase, decreases the need for epidural analgesia and the cesarean birth rate $(2,11)$, and increases childbirth motivation and comfort by reducing or controlling the anxiety of the pregnant women (9).
The aim of the present study was to identify the effect of birth ball exercise on the childbirth pain during the first stage of labor in primipara pregnant women.

\section{Method}

\section{Study Design}

The present study was a semi-experimental randomized controlled study conducted with participants who were about to give birth at a labor ward between February and May 2016 in Turkey. The annual number of births at this maternity hospital in 2015 was 988 . The women were randomly categorized into the intervention and control groups with an equal number of subjects in accordance with a computer-generated randomization list prepared by an independent statistician. The names of the distributed participants were given to the two certified nurses in sealed envelopes.

\section{Participants}

The inclusion criteria of the participants were as follows: pregnant women of age 18-35 years, who attended regular follow-up and pregnancy check-ups, in their $35^{\text {th }}$ week of gestation, without multiple pregnancy, with normal birth weight and vertex position, with planned normal spontaneous birth (the birth decision was determined by the certified nurses/ doctors and women), with a maximum cervical dilatation of 2 $\mathrm{cm}$, and who could possibly give term birth. Pregnant women unwilling to participate in the study were not included. Women who developed gestational hypertension and diabetes mellitus, underwent emergency cesarean section, had fetal anomalies, were using antipsychotic drugs, had hearing and communication problems, were physically disabled, or underwent epidural anesthesia were excluded from the study. Power analysis was used to determine the sample size. The sample size was determined as suggested by a previous study conducted by Gau et al. (8). The alpha level was taken as $0.05(\alpha=0.05)$ and reliability was accepted as $95 \%$ during the power analysis calculation. The sample size in our study was identified to be 26 participants for each group. However, taking the estimated attrition rate from the previous studies (40\%-60\%) taken into account, 42 participants were included in each study group. Finally, the study was completed with 30 participants in each of the groups.

\section{Data Collection Tools}

We used the data collection form that questioned the sociodemographic and obstetric characteristics of pregnant women for collection of the data in the study. The data collection form was created by investigators after reviewing relevant studies in the literature $(1,8,10,11)$. The form included 11 questions on socio-demographic characteristics (such as age and marriage duration) and 8 questions were related to obstetric characteristics (the number of prenatal follow-ups and prenatal education class attendance). A 10 centimeter $(\mathrm{cm})$ horizontal pain visual analog scale (VAS) was used to determine the pain level of the patients. The VAS included values of $0-10$ and is an extremely simple, effective, and repeatable pain severity measurement method. It is 
often used clinically to rapidly measure the pain severity. A VAS score of 1-3.9 is evaluated as "mild pain," 4-7.9 as "moderate pain," and 8-10 as "severe pain". Regarding the VAS validity, the ease of application is a significant advantage. The answers given after repetition of the test at short intervals were similar (15).

\section{The Intervention Program Used in This Study}

The birth ball exercise program involved provision of a tutorial booklet (of 26 pages) and an educational videocassette (19-minlong) $(16,17)$. The birth ball exercise program was created by obtaining the opinions of the relevant specialists (i.e., certified prenatal childbirth specialists, certified nurses, and physical therapist) and evaluation of the relevant literature by the investigators. The final state of the intervention program was developed based on the specialist opinions. The birth ball exercise program included 8 exercises in 4 different positions (i.e., sitting, standing, knelling, and squatting) $(8,11)$. However, before starting the exercise program with the pregnant women, the researchers determined the size of the birth balls that would be used for the exercise. The height and the leg length of each pregnant woman were measured. The size of the birth ball was determined according to the leg length of the pregnant woman. Two different ball sizes were used in this study $(55-\mathrm{cm}$ - and 65-cm-diameter). Large balls (65-cm-diameter) were used for long-legged pregnant women and small balls (55-cm-diameter) were used for short-legged women. In order to ensure the safety of the women in the intervention group, the balls were fully inflated and no objects that could cause injury were left in the exercise area.

The investigators informed each intervention group participants face-to-face about the exercises program, birth ball exercise education, and implementation of the exercise with the required positions from the $35^{\text {th }}$ week onward. Exercises and positions were performed once a week under the supervision of the investigators at the hospital (approximately 20-25 min for each session) to ensure the compliance of the women in the intervention group and their partners with the exercise program at the beginning. The women in the intervention group and their partners were also asked to implement the exercises and the positions for $20 \mathrm{~min}$ at least 3 times in a week at home for approximately 6-8 weeks. The questions of the women in the intervention group about the birth ball exercise program were answered during the weekly hospital training sessions and the prenatal follow-ups conducted every 2 weeks. Moreover, the women in the intervention group were also informed that they could leave the study if they could not implement the birth ball exercise program.

The control group received no birth ball training and performed no birth ball exercises. Women in both the groups received prenatal care (7-9-times on an average) and the routine hospital care during the regular interventions. The progression of the fetus through the birth channel, which is characteristics of uterine contractions, and the health of the fetuses were followedup at frequent intervals during labor in both the groups. Vaginal examinations were performed every $2-4 \mathrm{~h}$ during the birth to determine cervical dilatation by certified nurses and doctors.
All women and infants received care from the obstetricians and nurses in the prenatal and postnatal periods. In addition, each nurse routinely followed-up a maximum of 3 pregnant women.

\section{Data Collection}

The women meeting the study inclusion criteria were randomly divided into 2 groups. The passage of the participants through each trial stage is presented in Figure 1. The investigators required that the women of both groups visit the hospital when they develop uterine contractions at every 15-20 min. The cervical dilatation was $2 \mathrm{~cm}$ at this point of time, and the women who came to the hospital were included in the study groups. In addition, routine nursing care was provided by the hospital staff to both the groups. The investigators only collected the data about the women.

\section{Intervention Group}

The investigators were informed by the nurses at the hospital delivery room when the women reached the hospital to give birth. The cervical dilatation of the women in the intervention group was identified after the initial examination. The pregnant women were administered the data collection form and the VAS by the investigator when the cervical dilatation was $2 \mathrm{~cm}$. The cervical dilatation was determined with a vaginal examination every $2-4 \mathrm{~h}$, and the fetal condition, duration, frequency, and severity of the uterine contractions were routinely followedup. Later, the women in the intervention group were provided with a birth ball of an appropriate relevant size to implement the exercise program during childbirth. The women were encouraged to use the most comfortable positions, movements, and exercises every hour during childbirth by the nurses. The birth ball exercises, movements, and positions were implemented under the supervision of certified nurses. Rest intervals were allowed when the women were tired. The partners of the women acted as passive coaches during the childbirth process. The VAS scores of the women in the intervention group were inquired and registered in the latent period when the uterine contractions developed every 4-5 min and the cervical dilatation was $4 \mathrm{~cm}$. The cervical dilatation was expected to reach $6 \mathrm{~cm}$ when the uterine contractions developed every 2-3 min and to $8 \mathrm{~cm}$ when they developed every 1-2 min. The VAS scores were registered again when the cervical dilatation was $6 \mathrm{~cm}$ and $8 \mathrm{~cm}$, respectively.

\section{Control Group}

The investigators were informed by the nurses at the delivery room of the hospital when the women in the control group arrived at the hospital to give birth. The initial examination of the women in the control group was performed and cervical dilatation was determined, followed by a close follow-up. The investigator administered the data collection form and VAS while the cervical dilatation was $2 \mathrm{~cm}$. The VAS values were registered again when the cervical dilatation was 4,6 , and $8 \mathrm{~cm}$, respectively.

The data collection form was completed, and the VAS score was registered in both the groups in approximately 10-12 min while the cervical dilatation of the participants was $2 \mathrm{~cm}$. The VAS 
scores were registered at 1-2 min while the cervical dilatation was $4 \mathrm{~cm}, 6 \mathrm{~cm}$, and $8 \mathrm{~cm}$, respectively. All questionnaires were administered between these uterine contractions. All the questions in the questionnaire and the VAS were read by the investigators and answered by the participants.

\section{Ethical Considerations}

The data were collected after receiving approval from the hospital, and the clinical research ethics committee of a university (study no: 99950669/54 on 2016). All women included in the study were explained about the purpose of the study. The protocol and the procedures to be used (and their advantages/disadvantages) were explained to all participants, and their written consent to participate in the study were voluntarily obtained. All participants were told that they could leave the study at any time and that their health care would not be compromised in any case. In addition, the nurses and obstetricians in the delivery room of the hospital where the study was being conducted were informed about the purpose and the method of the study.

\section{Data Analysis}

The Statistical Package for Social Sciences (SPSS) version 16.0 was used for the data management (SPSS Inc., Chicago, IL, USA). The means and standard deviations of continual variables (VAS level) along with the frequencies and percentages of binary variables (sociodemographic and obstetrical variables) were computed using the SPSS version 16. The chi-square test $\left(\mathrm{X}^{2}\right)$ and independent $\mathrm{t}$-test were used to analyze the group difference. Repeated measurements analysis of variance were used to detect whether there were any differences between the pain measurements in the intervention and control groups as well as to determine the differences among the in group measurements.

\section{Results}

A total of 84 women were included in the study at first, 42 each in the intervention and control groups. However, some women were later excluded from the study due to various reasons such as emergency cesarean section $(n=9)$, epidural anesthesia $(n=9)$, preterm labor $(n=3)$, post-term labor $(n=1)$, and unwillingness to continue the study $(n=2)$ (Figure 1$)$. Twelve women from the intervention group and 12 from the control group were excluded because their attrition rate was $28.6 \%$. Finally, 30 women from the intervention group and 30 from the control group were included in the study. No statistically significant difference was observed when some of the socio-demographic data [such as age, education level, prenatal class attendance, performing Pilates, body mass index (BMI), duration of marriage] were compared between the women excluded from the study $(n=24)$ and those who completed the study $(n=60)(p>0.05)$.

Among the 60 women who completed the study, the mean age was 28.4 [standard deviation (SD): 2.8] years. The mean BMI was 24.6 (SD: 2.4), and the mean marriage duration was 4.0 (SD: 0.9) years. All pregnant women were primiparous. It was determined that $45 \%$ of the women were university graduates, $50 \%$ were housewives, and 55\% had a "medium" income.
Moreover, it was found that $48.3 \%$ of the women attended the prenatal education classes and $85 \%$ did not perform Pilates. Some sociodemographic data (such as age, education level, prenatal education class attendance, performing Pilates, BMI, the duration of marriage) of the women in the intervention and control group were compared, with no statistically significant difference between the groups (Table 1, p>0.05).

The mean gestational age of the women was 39.6 (SD: 0.8) weeks. We found that $61.6 \%$ of the women were satisfied with the passive coaching of their partner during the childbirth process, and $65.0 \%$ of the women received induction. Some obstetric data (such as gestational age, satisfaction with the passive coaching of the partner, and induction) were compared between the intervention and control groups; the difference was not considered to be statistically significant (Table 2, p>0.05).

VAS score comparisons of the women from the intervention and control groups are shown in Table 3 and Figure 2, respectively. We detected that birth ball exercise reduced the birth pain. The VAS score difference $(0.60)$ between the intervention and control groups when the cervical dilation was $2 \mathrm{~cm}$ was not statistically significant $(\mathrm{F}=6.141, \mathrm{p}=0.016)$. The VAS score difference $(0.80)$ between the intervention group and the control group when

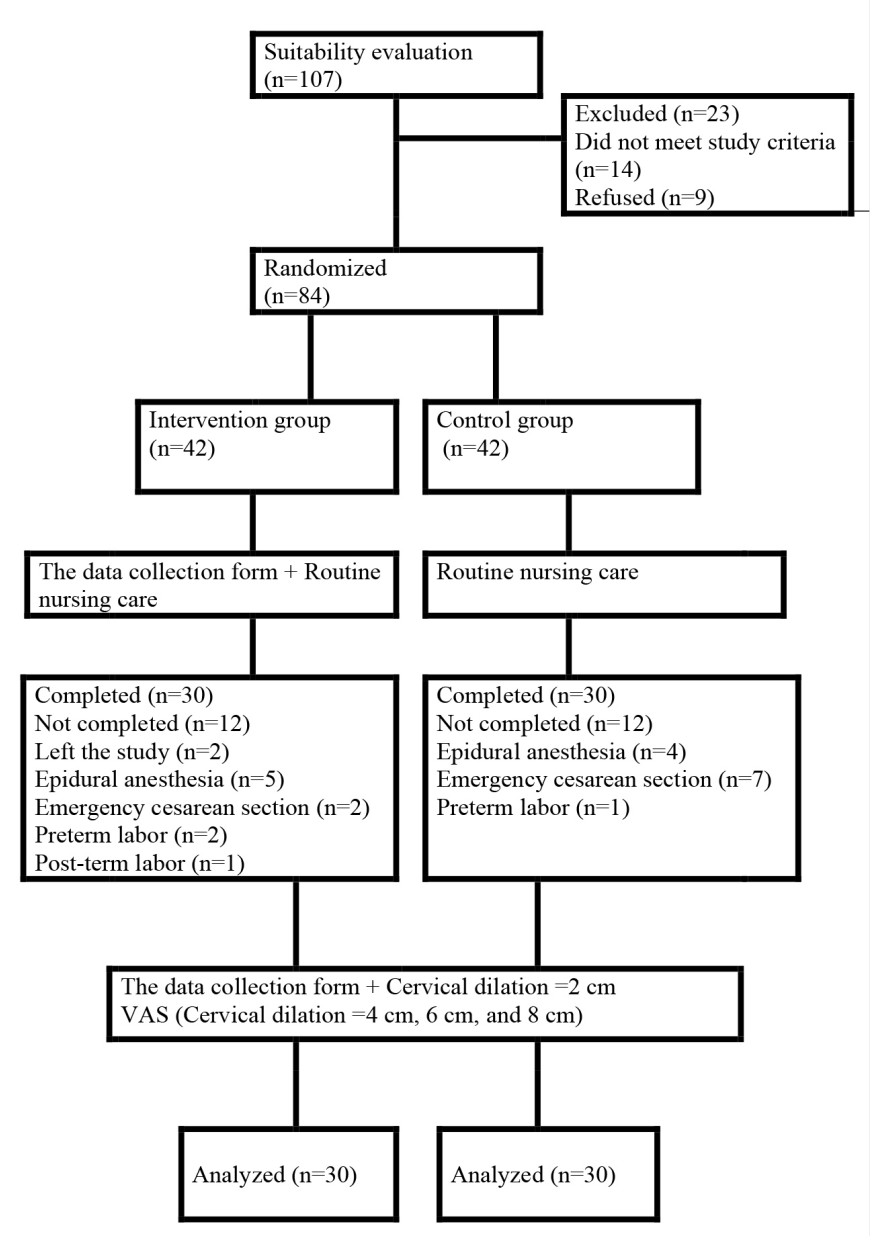

Figure 1. Passage of participants through each trial stage 
the cervical dilatation was $4 \mathrm{~cm}$ was found to be statistically significant $(\mathrm{F}=6.146, \mathrm{p}=0.010)$. The VAS score difference $(1.50)$ between the intervention group and the control group when the cervical dilatation was $6 \mathrm{~cm}$ was also statistically significant $(\mathrm{F}=8.660, \mathrm{p}=0.001)$. In addition, the VAS score difference (2.60) between the intervention and control groups when the cervical dilatation was $8 \mathrm{~cm}$ was found to be statistically significant $(\mathrm{F}=25.870, \mathrm{p}=0.001)$. These results indicate that the pain scores of the women in the intervention group who implemented birth ball exercises were significantly lower those of the women in the control group when the e cervical dilation was $4-8 \mathrm{~cm}$. The pain severity was "moderate" in the intervention group, but "severe"

Table 1. Distribution of some socio-demographic characteristics of the participating women

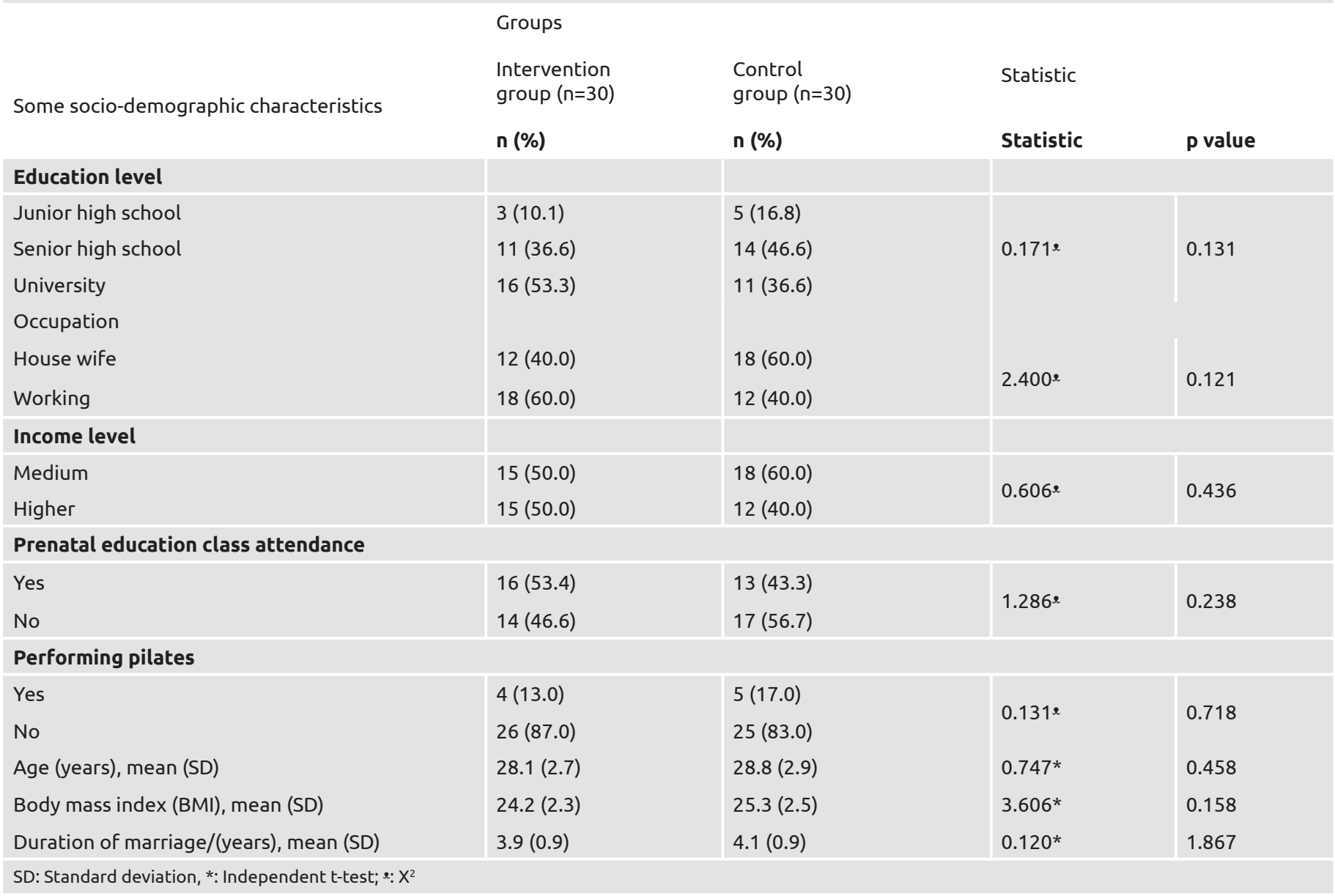

Table 2. Distribution of some obstetric characteristics of the participating women

\begin{tabular}{|c|c|c|c|c|c|}
\hline \multirow[b]{2}{*}{ Some obstetric characteristics } & \multicolumn{5}{|l|}{ Groups } \\
\hline & $\begin{array}{l}\text { Intervention } \\
\text { group }(\mathrm{n}=30) \\
\text { n (\%) }\end{array}$ & $\begin{array}{l}\text { Control } \\
\text { group (n=30) } \\
\text { n (\%) }\end{array}$ & $\begin{array}{l}\text { Overall } \\
(\mathrm{n}=60) \\
\mathbf{n}(\%)\end{array}$ & Statistic & p value \\
\hline \multicolumn{6}{|c|}{ Satisfaction with the passive coaching of the partner } \\
\hline $\begin{array}{l}\text { Yes } \\
\text { No }\end{array}$ & $\begin{array}{l}21(70.0) \\
9(30.0)\end{array}$ & $\begin{array}{l}16(53.3) \\
14(46.7)\end{array}$ & $\begin{array}{l}37 \text { (61.6) } \\
23(38.3)\end{array}$ & $4.286^{e}$ & 0.179 \\
\hline \multicolumn{6}{|l|}{ Induction } \\
\hline
\end{tabular}


in the control group. Birth ball exercises were therefore found to be effective in decreasing childbirth pain in this study (Table 3, Figure 2).

Variables such as age, educational level, occupational status, income level, prenatal class attendance, performing Pilates, BMI, duration of marriage, gestational age, satisfaction from the extent of passive coaching provided by the partner, and induction were found to have no effect on the pain scores during the childbirth process of the women in both the groups.

\section{Discussion}

Birth ball exercises are one of the non-pharmacological intervention approaches useful in decreasing birth-related pain. These methods have been commonly used to control childbirth pain, especially in some countries of the Far East and Europe in the recent years, with much research as well $(13,18,19)$. However, there was no study yet on birth ball exercises in Turkey. Therefore, we believe that our study will contribute to the literature significantly. Movements in different positions such as sitting and squatting relaxes the muscles in the pelvic region and decreases the uterine contraction severity in pregnant women who are assigned with the birth ball exercise program. This exercise program increases the blood flow to the uterus

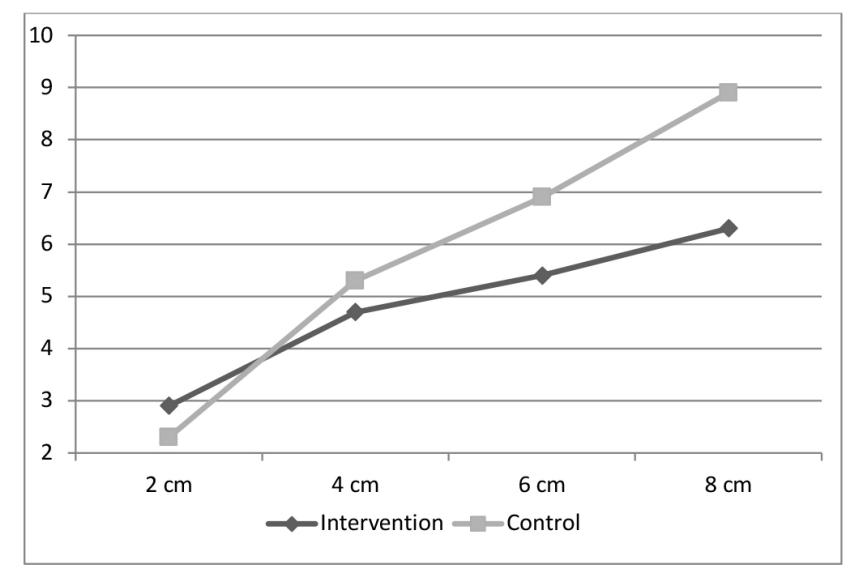

Figure 2. VAS score of the intervention and control groups VAS: Visual analog scale and decreases the associated pain $(11,19)$. In addition, pregnant women who control their bodies well during an exercise can also effectively manage their pain levels $(18,20)$. The soft surfaces of the balls used by the pregnant women in the birth ball exercise program decreases pain by reducing the pressure in the lower region of the back and providing support to the perineal region during the movements (8). The pain scores of the women in the intervention group were found to be significantly lower than those of the women in the control group when the cervical dilation was $4-8 \mathrm{~cm}$ in our study. The pain severity was "moderate" in the intervention group and "severe" in the control group. The birth ball exercise was therefore found to be effective in decreasing the childbirth-related pain in this study. The results of a randomized controlled study by Gau et al. (8) on 87 women also supported our results. Gau et al. (8) reported that the use of birth ball exercise can shorten the birth duration and decrease the need for epidural anesthesia and the related cesarean birth rate. Childbirth pain and the need for analgesia were found to decrease significantly after incorporating birth ball exercises in another study conducted by Leung et al. (11). Birth ball exercises has been found to be effective in the management of childbirth pain in several other studies as well $(3,12,14,19)$. Our study results are similar to those reported in the literature.

\section{Conclusion}

The VAS scores of the women in the intervention group who were assigned with birth ball exercises were found to be lower than those of the women in the control group with a statistically significant difference $(\mathrm{p}<0.05)$. The exercises were therefore found to be effective in decreasing the associated childbirth pain. Birth ball exercises can therefore be an alternative nonpharmacological intervention method in decreasing the childbirth pain. We therefore recommend the use of this exercise program by certified health professionals for the control or management of childbirth pain in the delivery room.

\section{Ethics}

Ethics Committee Approval: The data were collected after receiving approval from the hospital, and the clinical research ethics committee of a university (study no: 99950669/54 on 2016).

Table 3. VAS score comparisons of the women between the intervention and control groups

Groups

Intervention group

Control group

\section{VAS score}

$\operatorname{VAS}(2 \mathrm{~cm})$
$\operatorname{VAS}(4 \mathrm{~cm})$
$\operatorname{VAS}(6 \mathrm{~cm})$
$\operatorname{VAS}(8 \mathrm{~cm})$

VAS: Visual analog scale, SD: Standard deviation, $\uparrow$ : Variance analysis
Mean SD

\begin{tabular}{|l|l|}
\hline 2.90 .8 & 2.31 .0 \\
\hline 4.70 .9 & 5.50 .9 \\
5.41 .2 & 6.90 .9 \\
6.30 .8 & 8.91 .2
\end{tabular}

\begin{tabular}{|l|l|l|l|}
\hline Mean SD & Mean SD & F & p $\dagger$ \\
\hline 2.31 .0 & 2.60 .9 & 6.141 & 0.016 \\
\hline 5.50 .9 & 5.10 .9 & 6.146 & 0.010 \\
6.90 .9 & 6.11 .1 & 8.660 & 0.001 \\
\hline 8.91 .2 & 7.61 .0 & 25.870 & 0.001
\end{tabular}


Informed Consent: In addition, the nurses and obstetricians in the delivery room of the hospital where the study was being conducted were informed about the purpose and the method of the study.

Peer-review: Externally peer reviewed.

\section{Authorship Contributions}

Concept: D.A., S.K., M.E., E.G.B., F.R.G., Design: D.A., S.K., M.E., E.G.B., F.R.G., Data Collection or Processing: D.A., S.K., M.E., E.G.B., F.R.G., Analysis or Interpretation: D.A., S.K., M.E., E.G.B., F.R.G., Literature Search: D.A., S.K., M.E., E.G.B., F.R.G., Writing: D.A., S.K., M.E., E.G.B., F.R.G.

Conflict of Interest: No conflict of interest was declared by the authors.

Financial Disclosure: The authors declared that this study received no financial support.

\section{References}

1. Mirzakhani K, Hejazinia Z, Golmakani N, Sardar MA, Shakeri MT. The effect of birth ball exercises during pregnancy on mode of delivery in primiparous women. JMRH2015;3:269-5.

2. Avcibay B, Alan S. Nonpharmacological methods for management of labor pain. Mersin University Journal of Health Sciences 2011;4:1824.

3. Hau WL, Tsang SL, Kwan W, Siu-King Man L, Lam KY, Ho LF. The use of birth ball as a method of pain management in labour. Hong Kong J Gynaecol Obstet Midwifery 2012;12:63-8.

4. Makvandi S, Roudsari RL, Sadeghi R, Karimi L. Effect of birth ball on labor pain relief: a systematic review and meta-analysis. J Obstet Gynaecol Re 2015;41:1679-86.

5. Sani RM. Cultural approach to birth pain. Hacettepe University Faculty of Health Sciences Journal 2015;1:1-7.

6. Yıldırım G, Şahin NH. Nursing approach in controlling labor pain. Cumhuriyet Universitesi Journal of Nursing School 2003;7:14-20.

7. Basgöl S, Beji NK. Common practices and evidence based approach in first stage of labor. Journal of Duzce University Health Sciences Institute 2015;5:32-9.
8. Gau ML, Chang CY, Tian SH, Lin KC. Effects of birth ball exercise on pain and self-efficacy during childbirth: a randomised controlled trial in taiwan. Midwifery 2011;27:293-300.

9. Kwan Winny SC, Chan S, Wan-Hon LI. The birth ball experience: outcome evaluation of the intrapartum use of birth ball. Hong Kong J Gynaecol Obstet Midwifery 2011;11:59-64.

10. Shu-Hui T, Chien-Huei K, Kuan-Chia L, Ching-Yi C, Meei-Ling C. Effects of birth ball exercises on labor pain and childbirth satisfaction. JNHR 2013;9:13-22.

11. Leung Regina WC, Jess Li FP, Leung Mary KM, Fung Brigitte KY, Fung Lawrence CW, Tai SM. Efficacy of birth ball exercises on labour pain management. HKMJ 2013;19:393-9.

12. Shallow H. My rolling programme: the birth ball ten years experience of using the physiotherapy ball for labouring women. MIDIRS Midwifery Digest 2003;13:28-30.

13. Delgado-García BE, Orts-Cortés MI, Poveda-Bernabeu A, Caballero-Pérez P. Randomised controlled clinical trial to determine the effects of the use of birth balls during labour. Enfermería Clínica 2012;22:35-40.

14. Taavoni S, Abdolahian S, Haghani H, Neysani L. Effect of birth ball usage on pain in the active phase of labor: a randomized controlled trial. JMWH 2011;56:137-40.

15. Eti Aslan F. The assesment methods of pain. Cumhuriyet Universitesi Journal of Nursing School 2002;6:9-16.

16. Chang CY, Yu MH, Chen JJ, Gau ML. Designed a VCD teaching birth ball exercises to assist parturient women during labour. J Health Sci Edu 2008;10:99-110.

17. Watkins SS. Get on the ball the "birth ball" that is! Inter J Childbirth Edu 2001;16:17-9.

18. Mathew A, Nayak S, Vandana K. A Comparative study on effect of ambulation and birthing ball on maternal and newborn outcome among primigravida mothers in Selecte Hospitals in Mangalor. Nitte University Journal of Health Science 2012;2:2-5.

19. Zaky HH. Effect of pelvic rocking exercise using sitting position on birth ball during the first stage of labor on its progress. Journal of Nursing and Health Science 2016;5:19-27.

20. Taşşı E, Sevil Ü. Nonpharmacological approach intended for labor pain. Electron J Gen Med 2007;17:181-6. 